Malabou, Catherine (2017) Power and performance at play : a question of life or death. In: Street, Anna, Alliot, Julien and Pauker, Magnolia, (eds.) Inter views in performance philosophy: crossings and conversations. London, U.K. : Palgrave Macmillan. pp. 127-138 reproduced with permission of Palgrave Macmillan. This extract is taken from the author's original manuscript and has not been edited. The definitive, published, version of record is available here: https://www.palgrave.com/us/book/9781349951918 


\section{Power and Performance at Play: A Question of Life or Death ? Catherine Malabou}

As I was gathering my thoughts in preparation for this essay, it occurred to me that the most radical and definitive approach to the concept of performance, according to all its meanings, was to be found in Nietzsche. Nietzsche allows us to affirm that the dynamism of all performances is always, in every case, the movement of life returning to itself. Ecce Homo can undoubtedly be read as the first philosophical performance which puts into play, in the form of an autobiography, the way in which life comes back to itself. Here and now, I call myself, I quote myself (why I am so wise, why I am so clever, why I write such good books, why I am a destiny). Here and now, I settle somewhere in the middle of the ring that my life forms with itself, I call my life, my life calls out to itself, and it answers itself, and it comes back, it hears the call, my life hears itself, hears myself calling it and answers, and comes back, and recurs. I call out my life and it calls me back, and this is the highest form, the highest performance, the most intense energy, this return, life returning to itself, to me, the possibility that life affects itself, here, now, flowing and returning, like two hands joining, mutually offering to wear the same ring, to share the same loop, just for a moment even, the moment of the great noon. Nietzsche will say, now, here, with this voice, now, here, on that scene, with this body, with you watching me, my life watching me, watching itself, calling out to itself and making me feel alive, I intensively feel this body which speaks, I secretly hear my name, right now - that is eternally, eternally because I want to live this moment an infinite number of times again. Eternal recurrence is the movement of life performing itself.

Remember the beginning of Ecce Homo: "On this perfect day, when everything has become ripe and not only the grapes are growing brown, a ray of sunlight has 
fallen onto my life: I looked behind me, I looked before me, never have I seen so many and good things together. (...) How should I not be grateful to my whole life? And so I tell myself my life."1

As we will see, the kind of performance at play here gathers the three main meanings of the term; accomplishment or actuality, playacting, and art performance. Again, the loop that life forms with itself is the form of all performance, the protoform.

Before I explain why it is so, let me interrupt myself, or, more exactly, let me be interrupted by Derrida's death sentence, a sentence which dismantles the circle, breaks the ring, and disrupts the return.

In Otobiographies, Derrida acknowledges the fact that Ecce Homo "situates the place from which life will be recited, that is to say reaffirmed - yes, yes, (...). It is life that has to return eternally (...) as life allied to itself by the nuptial annulus, the wedding ring." ${ }^{, 2}$ And yet, against Nietzsche, Derrida states that this return, this alliance is impossible. Life always divides itself, destructs itself, exhausts itself because of the split which forever disjoints the name from the bearer of the name, Nietzsche from Nietzsche, the living from the dead. Here comes the death sentence: "Only the name can inherit, and this is why the name, to be distinguished from the bearer, is always and a priori a dead man's name, a name of death. What returns to the name never returns to the living. Nothing ever comes back to the living."

Derrida interprets the scene of Ecce Homo where life performs its own return, performs itself as its own capacity to return, as a scene of signature, as the very economy of signature even: Nietzsche calls himself and signs and thus "puts his body and his name out front." And this circle between the life that lives and the life that 
signs fails to accomplish itself, it fails because nothing ever comes back to the living. Life always comes back dead.

Such would be the law of all performance that it erases the performer, that it remains forever unaccomplished, that no "surplus value," as Derrida also says, ever benefits the living. ${ }^{5}$ The conatus is bound to lose.

In his beautiful article "Transcending Mere Survival: From Conatus to Conatus Intelligendi," Yirmiyahu Yovel shows that in Spinoza already, "what emerges is a desire not only for self-preservation, but also for eternity: conatus is revealed to be the finite mode's striving to overcome its finitude and link onto the atemporal and eternal," "6 understood as a desire for intensification of life. I am not only endeavoring in my being to live longer but to "live more" intensively. "The desire I am is not directed at any particular gratification, but enhancing my existence and power of being."

Here again, Derrida's death sentence interrupts the desire. The conatus, because it has to sign, because it bears a name, always escapes its own intensity, its own intensification evaporates, squanders itself, fragments itself. The ring of life is forever broken.

Heidegger is in a way wrong then to affirm that the two Nietzschean doctrines of Eternal Recurrence and of the Will to Power do not contradict each other but are intimately linked with one another. ${ }^{8}$ It seems on the contrary that the will to power is always deceived by the return because the return is precisely impossible, or is only possible as the return of the dead, and the defeat of the will. Eternal recurrence would be the lethal threat to power, the mortal poison inherent to the will to perform.

What do we mean by "perform" here and what is a philosophical performance for Nietzsche? Let's go back to the three meanings of the term. First, 
accomplishment, actuality, the act of doing something. Second, playacting, and third, art performance. In all cases, a determined and specific definition of power is at stake.

What does philosophy perform in the first place? From where does philosophy draw its discursive power? Traditionally, the specific accomplishment of philosophy, what philosophy is said to perform in the first sense, are judgments and predications. Philosophy works, operates on propositions.

All philosophical propositions are complex event types that involve the performance of certain basic acts. By accomplishing the complete determination of the predicate, and if the right act of determination has been performed, the judgment causes the predicate to exist. The philosophical proposition always makes things with words by redoubling the natural existence of the thing, producing its logical determination. The power of philosophy then resides in the capacity of such a redoubling, which is a creation of reality.

In what way is this meaning present in Nietzsche? Nietzsche precisely reveals the very structure of logical propositions to be the mask of the fundamental relationship of life with itself. Nietzsche shows that philosophical propositions, whatever their types, have always been expressions of the predicative circle of life.

When life calls out to itself, comes back to itself, the subject calls itself as a predicate, as an object, as an accident which turns out to be essential. "Object," Nietzsche says, "is only a kind of effect produced by a subject upon a subject - a modus of the subject." An object thus emerges as a subject coming back to itself and affecting itself in this loop. Judgments and propositions translate the biological movement of auto-affection by which life puts itself at a distance with itself and then re-appropriates itself. Judgment is life. Judgment belongs to the self-regulative 
functions which already exist in the most inferior of all organic creatures. Judgment is older than the drive in the development of organic life.

In Nietzsche, the logical form of the proposition explodes to reveal its hidden heart: the energy of life as the eternal recurrence of the accident in the essence and of the essence in the accident.

Here we meet theatrical performance, the second meaning of the term. In order to unmask the genuine structural identity of the proposition, we have to literally put it into play in a proposition simulacrum, like I am whom I become, I become who I am. Why I am so wise. Why I am so clever. Why I write such good books. These simulacra express the profoundly fictitious and theatrical essence of logic. Theater, as it is already announced in The Birth of Tragedy, accomplishes the debasement of ontology. And such a debasement cannot be granted once and for all, otherwise it would constitute a new dogma among others. It has to take place here and now, like an art performance (the third meaning of the term), at this very moment, in this very instant, in an eternally recurring present.

Behind logic there is power, that is will to power. "My doctrine is: Live that thou mayest desire to live again." This intensification of life through its own return, the very performance of life as return, a logical, theatrical, and artistic performance, appears as the supreme power understood by Nietzsche as the supreme effort, the supreme energy, the highest dynamism, the capacity to not back up in front of anything, and first of all in front of one's own creative force.

This empowering circle of life appears to Derrida as a form of sovereignty, the very form of sovereignty in fact. Under a deconstructive mask, Nietzsche appears as the philosopher who announces a new structure of sovereignty. Here we cannot but underscore the profound affinity between the concepts of performance and 
sovereignty. In showing that death is always already interrupting such an alliance and affinity, Derrida affirms, against Nietzsche, that the defeat of power - inherent to eternal recurrence - allows us to witness the defeat of performativity, that is, of sovereignty, at work in all philosophical propositions.

In another text devoted to the problem of signature, the famous Signature, Event, Context, Derrida shows how iterability - that is, again, return - always undermines the performative which is contained in all judgments to the extent that they actualize the predicate. A performative utterance, Derrida recalls, “transforms," "produces," "operates." It makes things exist. It is an act. This act supposes the return of what is done or acted to the subject of enunciation, of "a free consciousness present for the totality of the operation, of an absolutely full meaning that is master of itself." ${ }^{10}$ Meaning has to return to itself, and this loop constitutes the performative dimension of all logical utterances, including even those that are not specifically performative - even ones like "How one becomes what one is" - creating the conditions of possibility for the power of doing things with words. The problem, Derrida goes on in the same way as in Otobiographies, is that "given [the] structure of iteration, the intention which animates utterance will never be completely present in itself and its content."11 “"Death', or the possibility of the 'death' of the addressee [is] inscribed in the structure of the mark... And this absence," Derrida goes on, "is not a continuous modification of presence; it is a break in presence."12 This is also what Derrida calls "the effects of signature" ${ }^{, 13}$ within the performative, effects which, once again, prevent the return of life or meaning to itself.

The performative is rendered impossible by the non-performative modalities of its utterings. The impossibility of the performative, and not its possibility - contrary to what Nietzsche affirms, enables its iterability, that is its eternal return. 
In the The Beast and the Sovereign, Derrida suggests that sovereignty constructs itself by means of a performative speech act, which is of a fabular and even theatrical kind. Sovereignty sets itself up by way of the invocation of fear ${ }^{14}$ and the assertion of the right of the strongest: "I am right because I am called the lion and you will listen to me ... I am the strongest, and I will finish you off if you object." ${ }^{, 15}$ How not to interpret Nietzsche's self-call as a version of such a speech act? How not to notice the proximity between the sovereign's self-address and the way in which life comes back to itself?

This point is particularly important in contemporary political philosophy. Agamben's analysis of sovereignty as developed in Homo Sacer confirms the fact that sovereignty is structured like a proposition or a predication. The subject's sovereignty consists in the fact that it is always its own predicate, that is its own exception. My essence consists in the fact that I am exceptional - and sovereignty precisely coincides with the concept of exception, a coincidence which is highly paradoxical, because it means that exception is the rule. Sovereignty, Agamben says, implies "the state of exception as... [a] permanent structure." ${ }^{\text {16 }}$ If supreme power is founded upon exception, that means that there is no way in which we can rigorously distinguish between the exceptional and the essential. Does not eternal recurrence, within which essence and the accident enter a "zone of indifference," within which the law, the return, and the exception, (the singular subject, the bearer of the name Nietzsche for example), appear to be the very structure of absolute power?

Besides, Agamben shows that the modern form of sovereignty lays its foundation on the erasure of the difference between two determinations of life, bios and zoè, or qualified life and bare life. We can't but acknowledge the fact that what Nietzsche calls life everywhere in his philosophy, and which is made particularly 
obvious in Ecce Homo, is both, at once, biological and symbolic, natural and spiritual. It would be impossible to draw a strict frontier between bios and zoè in Nietzsche. Natural life - which expresses itself in Ecce Homo as bodily dispositions, medical conditions, diet - constantly echoes symbolic life - books, writings, spiritual destiny and the ring of the return holds together bios and zoè indistinctively. Such is the performance: that life returns to itself as both zoè and bios, which are in turn essence and accident of the same proposition.

The only solution to preserving Nietzsche from the absoluteness of his own sovereignty then consists in reading him against himself, in deflating his sovereignty, in undermining the performance, or interrupting the circle of life. Nietzsche should be "discharged and divested from all sovereignty.","

Such a discharging reading is precisely the one Derrida undertakes in Otobiographies, as we saw, by introducing death into the circle. Life cannot return to itself. What returns to the name never returns to the living. Nothing ever comes back to the living. This disjuncture is also what creates a gap between the symbolic and the biological, between life and itself. It is important to disrupt the continuity, to open the circle to alterity - and again, this is what Derrida does. During the "Round Table on Autobiography," which follows the conference and is also published in The Ear of the Other, Derrida insists upon the fact that Nietzsche's performance, the scene of signature, never happens: "Nietzsche has great trouble signing. He wants to sign but he is obliged to defer his signature, to entrust it to something like the eternal return which will not sign just once by stating an identity. (...) He defers its signature." ${ }^{18} \mathrm{He}$ cannot be "the strongest.",19

This deferral of différance means that there is always someone else in me, an intrusion that breaks the logic of auto affection, auto predication and self-address. 
Ecce Homo then can and must be read, from the point of view of this hetero-affection, as a non-sovereign performance, where power is never actual, where life never returns to itself, where energy is squandered, disseminated, lost. Derrida goes on: "every name is the name of someone dead, or of a living someone whom it can do without." ${ }^{20}$ He adds:

The most important thing (...) is that the signature becomes effective performed and performing - not at the moment it apparently takes place, but only later, when ears will have managed to receive the message. In some way the signature will take place on the addressee's side, that is, on the side of him or her whose ear will be keen enough to hear my name, for example, or to understand my signature, that with which I sign. (...) Here one may derive the political import of this structure and of this signature in which the addressee signs with his/her ear, an organ for perceiving difference. As regards Nietzsche for example, it is we who have to honor his signature by interpreting his message and his legacy politically. On this condition, the signature contract and the autobiography will take place. It is rather paradoxical to think of an autobiography whose signature is entrusted to the other (...). But it is not Nietzsche's originality that has put us in this situation. Every text answers to this structure. It is the structure of textuality in general. A text is signed much later by the other. ${ }^{21}$

["The ear of the other says to me and constitutes the autos of my autobiography",22]

If the other signs in my place, it means that I am dispossessed of my own sovereignty or power. The problem of a non-sovereign power, which is also the problem of a non-performative power, has become a key question in the philosophy of the end of the twentieth century. Deconstructing sovereignty implies the interruption of self-foundation, self-sufficiency, of the relationship between the sovereign and itself as the origin of all limits or boundaries, as that which decides inclusion and exclusion, and determines the rule and the exception.

In order to move away from the sovereign exception, Agamben says we have to think of a kind of power which is at the same time a non-power, something he calls “impotentiality.” A power whose potentiality never actualizes itself. A pure virtuality: "One must think the existence of potentiality without any relation to Being in the 
form of actuality - not even in the extreme form of the ban and the potentiality not to be, and of actuality as the fulfillment and manifestation of potentiality."23

Deprived of energy, of energeia, performance then cannot be thought as a circle anymore, a circle of the proposition (circularity between the essence and the accident), a circle of the theatrical scene (sphere of self-representation or of the account of oneself), or a circle of eternal return of the identical in the present moment.

Nietzsche being read against himself - as is the case in so many interpretations of the end of the twentieth century - becomes a living dead. As Genet quoted by Derrida says: "My theater is addressed to the dead." 24 The energy of life coming back to itself in the live performance of Ecce Homo fades away and dissolves in the neutrality and invisibility of the Homo Sacer. We then have Ecce Homo Sacer.

What remains of the will to power today appears to be this "living body that seems no longer to belong to the world of the living." 25 Nietzsche, a living dead, a survivor.

It then seems that we cannot read Nietzsche without performing the other in him, thus distorting his signature and disjointing the unity of his self, his body, and his life. It then seems that we cannot read Nietzsche without performing Bartleby in Zarathustra. Bartleby has become the archetype of the non-performative, nonsovereign and non-actual subject. "In modern thought, there are rare but significant attempts to conceive of being beyond the principle of sovereignty. (...) The strongest objection against [this] principle is contained in Melville's Bartleby, the scrivener who, with his 'I would prefer not to', resists every possibility of deciding between potentiality and the potentiality not to."26 "I would prefer not to" would then be the anti-proposition which undermines all predication and, in spite or because of its 
iterability, eternal recurrence itself. Bartleby serves as the model of all artistic identity at the end of the twentieth century.

My question asks: Is impotentiality - or the potentiality not to - the only way to deconstruct sovereign power? Is it the only way to deconstruct performativity?

It seems that each of the philosophers I have referred to wish to protect Nietzsche against all forms of biologism. Derrida's sentence, "nothing ever comes back to the living," can of course be understood as an expression of this antibiologism. As if it were necessary to dissociate life in order to preserve it from its own power. I wonder, however, if this anti-biologism does not induce another kind of sovereignty. Or if it does not coincide with the distinction made by Kantorowicz in his famous book The King's Two Bodies, between the natural and the symbolic or eternal body of the sovereign. When they insist upon the urge to let the other in, aren't Derrida and Agamben presupposing that bios and zoè can be separated, to the extent that they affirm that the symbolic dimension of the other, the abstract character of the signature, always comes to interrupt the circle of the living, thus dividing the profound unity of its biological and symbolic meanings as it appears in Ecce Homo? How then can we deconstruct the sovereign power of life without reintroducing the sovereign division between two bodies - the two bodies of the sovereign? Who is the utterly other if not the sacred corpse which prevents the natural self from coinciding with itself but which then also spiritualizes it and transforms it into a symbolic instance - something more essentially eternal, if I may say so, than eternal recurrence itself?

Impotentiality cannot be the answer. It cannot be the only political and philosophical solution. It is too depressing. Too disappointing. Too uninteresting and ineffective. 
Let us return Nietzsche to himself, let us invent a new approach to life, with its unity, power and energy.

On this perfect day, when everything has become ripe and not only the grapes are growing brown, a ray of sunlight has fallen on to my life: I looked behind me, I looked before me, never have I seen so many and good things together. (...) How should I not be grateful to my whole life? And so I tell myself my life. $^{27}$

Isn't there a possibility for the living to return to itself? When I call myself, is my life not returning to itself, like an animal? When I call myself as I call out to my cat, when I call myself to feel that I am alive, in an animal way, is it necessarily a form of auto-affection or isn't it also a way to forget about myself, but be alive, a way to escape myself in rapture, but be alive? Isn't it like calling out to myself in a foreign language? When I write in another language, as I am currently doing, when my life meets with itself in two or more different idioms and bodies, what happens? Does this encounter designate the closed form of a self or does it carry the self beyond itself, while yet alive?

Isn't there a way to be sovereign without being subjected to sovereignty?

\section{BIBLIOGRAPHY:}

AGAMBEN, Giorgio. Homo Sacer: Sovereign Power and Bare Life. Translated by Daniel Heller-Roazen. Stanford, CA: Stanford University Press, 1998.

DERRIDA, Jacques; DONATO, Eugenio. "A Third Logic. Reply.” In DERRIDA, Jacques. The Ear of the Other. Otobiography, Transference, Translation. Translated by Peggy Kamuf. Lincoln; London: University of Nebraska Press, 1988. $54-58$.

DERRIDA, Jacques; MCDONALD, Christie. "From One Genre To Another. Reply" In DERRIDA, Jacques. The Ear of the Other. Otobiography, Transference, Translation. Translated by Peggy Kamuf. Lincoln; London: University of Nebraska Press, 1988. 46 - 53.

DERRIDA, Jacques. Otobiographies: l'enseignement de Nietzsche et la politique du nom propre. Paris: Galilée, 1984.

---. Otobiographies: The Teaching of Nietzsche and the Teaching of the Proper Name. In DERRIDA, Jacques. The Ear of the Other. Otobiography, Transference, Translation. Translated by Avital Ronell. Lincoln; London: University of Nebraska Press, 1988. 1 - 40.

---. "Signature, Event, Context” In DERRIDA, Jacques. Margins of Philosophy. Translated by Alan Bass. Chicago: Chicago University Press, 1984. 307 - 330. 
---. The Poetics of Paul Celan. Edited by Thomas Dutoit and Outi Pasanen. New York: Fordham University Press, 2005.

HEIDEGGER, Martin. Nietzsche (volumes 1 and 2). Translated by David Farrell Krell. San Francisco: Harper, 1991.

NIETZSCHE, Friedrich. Ecce Homo. Translated and edited by Walter Kaufmann. New York: Vintage Books, 1967.

---. The Will to Power. Translated by Walter Kaufmann and R.J. Hollingdale. New York: Vintage Books, 1967.

YOVEL, Yirmiyahu. "Transcending Mere Survival: From Conatus to Conatus Intelligendi." In Desire and Affect: Spinoza as Psychologist (Ethica III), edited by Yirmiyahu Yovel, 45-61. New York: Little Room Press, 1999.

${ }^{1}$ Friedrich Nietzsche, Ecce Homo, trans. Walter Kaufmann (New York, Vintage Books, 1967), epigraph.

${ }^{2}$ Jacques Derrida, Otobiographies: The Teaching of Nietzsche and the Teaching of the Proper Name, in The Ear of the Other, trans. Avital Ronell (Lincoln, London, University of Nebraska Press, 1988), 14.

${ }^{3}$ In French the last sentence is even more radical: «Rien de vivant ne revient à $d u$ vivant. » in Derrida, Otobiographies: l'enseignement de Nietzsche et la politique du nom propre. (Paris: Galilée, 1984), 7.

${ }^{4}$ Ibid, 7.

${ }^{5}$ Ibid, 7.

${ }^{6}$ Yirmiyahu Yovel, "Transcending Mere Survival: From Conatus to Conatus Intelligendi", in Desire and Affect : Spinoza as Psychologist, Ethica III, ed.

Yirmiyahu Yovel (New York, Little Room Press, 1999), 47.

${ }^{7}$ Ibid, 48.

${ }^{8}$ Martin Heidegger, Nietzsche volume 1: The Will to Power as Art, trans. David Farrell Krell (San Francisco, Harper, 1991), 19 sq.

${ }^{9}$ Friedrich Nietzsche, The Will to Power, trans. Walter Kaufmann and R.J.

Hollingdale (New York, Vintage Books, 1967), 307.

${ }^{10}$ Jacques Derrida, "Signature, Event, Context," in Margins of Philosophy, trans.

Alan Bass (Chicago, Chicago University Press, 1984), 323.

${ }^{11}$ Ibid, 326.

${ }^{12}$ Ibid, 316.

${ }^{13}$ Ibid, 328.

${ }^{14}$ Jacques Derrida, The Beast and the Sovereign, Volume I, eds. Michel Lisse, MarieLouise Mallet, and Ginette Michaud, trans. Geoffrey Bennington, (Chicago:

University of Chicago Press, 2009), 214.

${ }^{15}$ Jacques Derrida, The Poetics of Paul Celan, eds. Thomas Dutoit and Outi Pasanen (New York, Fordham University Press, 2005), 109.

${ }^{16}$ Giorgio Agamben, Homo Sacer: Sovereign Power and Bare Life, trans. Daniel Heller-Roazen (Stanford, CA, Stanford University Press, 1998), 48.

${ }^{17}$ Ibid.

18 Jacques Derrida, Eugenio Donato, “A Third Logic. Reply," in The Ear of the Other, trans. Peggy Kamuf (Lincoln, London, University of Nebraska Press, 1988), 57.

${ }^{19}$ Ibid.

${ }^{20} \mathrm{Ibid}, 53$. 
${ }^{21}$ Jacques Derrida, Christie McDonald, "From One Genre To Another. Reply," in The Ear of the Other, trans. Peggy Kamuf (Lincoln, London, University of Nebraska Press, 1988), 50-51.

${ }^{22}$ Ibid, 51.

${ }^{23}$ Giorgio Agamben, Homo Sacer, 33.

${ }^{24}$ Quoted in Jacques Derrida, Eugenio Donato, “A Third Logic. Reply,” 53.

${ }^{25}$ Giorgio Agamben, Homo Sacer, 99.

${ }^{26} \mathrm{Ibid}, 48$.

${ }^{27}$ Friedrich Nietzsche, Ecce Homo, epigraph. 